Al-Azhar Bull. Sci. Vol. 19, No. 1 (June.): pp. 101-121, 2008.

\title{
EFFECT OF CALCINATION TEMPERATURE OF KAOLINITE CLAY ON THE PROPERTIES OF PORTLAND CEMENT PASTES CONTAINING METAKAOLIN
}

\author{
M.A.TAHER, A.Y.EL-SAYED , O.A.FARGHALY AND M.R.SHATAT \\ Chemistry Department. Faculty of Science, Al-Azhar University, Assiut,Egypt
}

\begin{abstract}
Metakaolin (MK) is a highly reactive pozzolan produced by calcination of kaolinite clay at high temperatures. It has a high specific surface, which makes it very suitable as a cementing material in concrete. The utilization of area calcined clay, in the form of MK, as a pozzolanic material for mortar and concrete has received a considerable attention in recent years. This interest is part of the widely spread attention directed towards the utilization of wastes and industrial by-products in order to minimize Portland cement (PC) consumption, the manufacture of which being environmentally damaging. Another reason is that mortar and concrete, which contain pozzolanic materials, exhibit considerable enhancement in durability properties. In this investigation, the physico-chemical properties of artificial pozzolanic cement pastes containing MK produced by calcination of kaolinite clay at different temperatures $\left(700,800,900\right.$, and $\left.1000^{\circ} \mathrm{C}\right)$ were studied. PC was partially substituted for by 0 , $5,10,15$ and $20 \%$ of MK by weight at different calcination temperatures. The characteristics of prepared mortars were investigated after curing in water for different periods $(3,7,28$ and 90 days) by determination of compressive strength and total porosity. The hydration kinetics was evaluated by determination of free lime contents. IR spectroscopic analysis was used to investigate the change in structure of mortars after curing. The change in morphology and microstructure of some hardened pastes were investigated by scanning electron microscopy (SEM).
\end{abstract}

Keywords: Metakaolin, Pozzolan, Kaolin, Blended cement.

Abbreviations: $\mathrm{C}=\mathrm{CaO} ; \mathrm{S}=\mathrm{SiO}_{2} ; \mathrm{H}=\mathrm{H}_{2} \mathrm{O} ; \mathrm{A}=\mathrm{Al}_{2} \mathrm{O}_{3} ; \mathrm{F}=\mathrm{Fe}_{2} \mathrm{O}_{3} ; \mathrm{CH}=$ $\mathrm{Ca}(\mathrm{OH})_{2}$

Corresponding Author: M.A.Taher

E-mail Address: mahmoudtaher@excite.com

\section{Introduction}

Metakaolin (MK) has been introduced recently as a highly active and effective pozolans for the partial replacement of cement in concrete. It is an ultra fine material produced by the dehydroxylation of a kaolin precursor upon heating in the temperature range of $700-800^{\circ} \mathrm{C}$ [1]. The calcinations conditions are the main factors, which can modify the reactivity of $\mathrm{MK}$. Reactive MK can be obtained between $700-900^{\circ} \mathrm{C}$. On calcining clays up to $1000^{\circ} \mathrm{C}$, some physico-chemical 
processes occur leading to change in the nature of these materials. Clays loose its adsorbed and chemically-combined water at the temperature range between 100$200^{\circ} \mathrm{C}$ and $500-700^{\circ} \mathrm{C}$, respectively. The dehydration of clays gives an amorphous mixture of $\mathrm{Al}_{2} \mathrm{O}_{3}$ and $\mathrm{SiO}_{2}(\mathrm{MK})$. At a temperature lower than $700^{\circ} \mathrm{C}$, residual kaolin occurs, whereas above $900^{\circ} \mathrm{C}$ the crystallization of metakaolin into $\gamma-\mathrm{Al}_{2} \mathrm{O}_{3}$ containing silica in its spinal structure starts, which diminishes greatly the reactivity of metakaolin [2]. $\mathrm{MK}$ is a silica-based product that, on reaction with $\mathrm{Ca}(\mathrm{OH})_{2}$, produces $\mathrm{CSH}$ gel at ambient temperature. MK also contains alumina that reacts with $\mathrm{CH}$ to produce additional alumina-containing phases, including $\mathrm{C}_{4} \mathrm{AH}_{13}$, $\mathrm{C}_{2} \mathrm{ASH}_{8}$, and $\mathrm{C}_{3} \mathrm{AH}_{6}[3,4]$. The physical and mechanical properties of PC containing MK or combination of MK and slag and the compatibility between such materials and superplasticizers were investigated [5]. After MK was incorporated into PC, the compressive strength of the blended cement was enhanced. An investigation was carried out on a range of concrete mixes with three different proportions of MK to replace ordinary Portland cement [6]. Both the aggregate-binder ratio and the waterbinder ratio were varied to yield concrete with a wide range of strength, workability and permeability. The results were used to establish the effect of mix constituents on strength, workability and permeability. It has been found that metakaolin used in different dosages to replace Portland cement changes properties of both the fresh and hardened concrete. It increases the compressive strength and reduces the slump for a given aggregate/binder ratio and water/binder ratio. The effect of using metakaolin as a cement replacement material on air permeability was found to be very marginal .Up to a maximum of $10 \%$ replacement level, the sorptivity of concrete is improved for high levels of cement content. The properties and the hydration procedure of cements containing metakaolin were monitored for periods up to 180 days [7]. Four metakaolins, derived from poor Greek kaolins, as well as a commercial metakaolin of high purity were used. Cement mortars and pastes, with $0 \%, 10 \%$ and $20 \%$ replacement of cement with the above metakaolins, were examined. Strength development, water demand and setting time were determined in all samples. In addition, XRD and TGA were applied in order to study the hydration products and the hydration rate in cement-metakaolin pastes. It was concluded that metakaolin has a very positive effect on the cement strength after 2 days and specifically at 28 and 180 days. Finally, it was concluded that a $10 \%$ MK content seems to be, generally, more favorable than $20 \%$. The stress-strain relationships 
(tension and compression) and bend strength measurements for concrete incorporating $0 \%, 5 \%, 10 \%$ and $15 \%$ MK were studied [8] . The test results showed that the tensile strength and peak strain increase with increasing MK content whereas the tensile modulus shows only small changes. Poon et al [9] studied the hydration progress in MK-blended high-performance cement pastes with age from the measurements of compressive strength, porosity, pore size distribution, the degree of pozzolanic reaction, and the $\mathrm{CH}$ contents of $\mathrm{MK}$-blended cement pastes at water/binder ratio $(\mathrm{w} / \mathrm{b})$ of 0.3 . Comparisons are also made with pastes containing silica fume (SF), fly ash (FA) and control Portland cement (PC). It was found that at early ages, the rates of pozzolanic reaction and $\mathrm{CH}$ consumption in the MK-blended cement pastes are higher than the SF- or FA-blended cement pastes. The higher pozzolanic activity of MK results in a higher rate of strength development and pore structure refinement for the cement pastes at early ages. Although the rate of pozzolanic reaction of MK becomes slower after 28 days of curing, the pozzolanic reaction in the blended cement pastes with a w/b of 0.3 still continues at the age of 90 days. At this age, about half of the MK still are unreacted. The effect of MK addition on the corrosion resistance of cement mortar was studied [10]. Several mixture proportions were used to produce mortar specimens, where metakaolin replaced either sand or cement. Mortar specimens were then exposed to the corrosive environment of either partial or total immersion in $3.5 \% \mathrm{w} / \mathrm{w} \mathrm{NaCl}$ solution. It was concluded that MK improves the compressive strength and the $10 \%$ w/w addition shows the optimum contribution to the strength development.

\section{Experimental}

\section{Materials:}

The materials used in this investigation are Portland cement (Assiut Company, Assiut, Egypt), kaolinite clay (Kalabsha, Aswan, Egypt). The chemical oxide composition of Portland cement and Kalabsha kaolinite clay used in this study is shown in Table (1). 
Table (1): Chemical oxide composition of Portland cement and Kalabsha kaolinite clay, (\% weight).

\begin{tabular}{|c|c|c|}
\hline Oxide contents & Portland cement & Kalabsha kaolinite clay \\
\hline $\mathrm{SiO}_{2}$ & 20.60 & 44.18 \\
$\mathrm{Al}_{2} \mathrm{O}_{3}$ & 5.50 & 36.75 \\
$\mathrm{Fe}_{2} \mathrm{O}_{3}$ & 3.75 & 1.36 \\
$\mathrm{CaO}$ & 63.55 & 0.26 \\
$\mathrm{SO}_{3}$ & 2.13 & ---- \\
$\mathrm{MgO}$ & 0.78 & 0.16 \\
$\mathrm{Na}_{2} \mathrm{O}$ & 0.44 & 0.18 \\
$\mathrm{~K}_{2} \mathrm{O}$ & 0.47 & 0.25 \\
$\mathrm{TiO}_{2}$ & 0.54 & 2.94 \\
L.O.I & 2.19 & 13.55 \\
Total & 99.95 & 99.63 \\
\hline
\end{tabular}

\section{Methods:}

Preparation of calcined clay (metakaolin):

Kalabsha Kaolinite clay (KK) was dried at $110^{\circ} \mathrm{C}$ for 48 hours, then crushed and passed completely through $1 \mathrm{~mm}$ B.S. sieve. The crushed clay was burnt at 700, 800, 900 and $1000^{\circ} \mathrm{C}$ for a soaking period of 2 hours and then quenched in air. The burnt clay (MK), after air quenching, was subjected to ball mill grinding for 20 minutes and passed through a $75 \mu \mathrm{m}$ B.S. sieve; the processes of grinding and sieving were repeated until the sample is passed completely through $90 \mu \mathrm{m}$.

Preparation of PC-MK specimens:

PC was mixed with four types of MK produced by burning Kalabsha kaolinite clay at $700,800,900$ and $1000^{\circ} \mathrm{C}$. Five dry mixtures were prepared from various proportions of PC and MK with the mass ratios of 100:0(B), 95:5(CI), 90:10(CII), 85:15(CIII), 80:20(CIV) and 75:25(CV), respectively, using ethanol to obtained complete homogeneity of the mixture; then dried overnight at $105^{\circ} \mathrm{C}$. Each dry mixture was mixed for three minutes at different workability water/solid ratios by weight. The resulting mass was molded in 1-inch cubic moulds. The moulds were vibrated for one minute to remove any air bubbles and voids. Immediately after moulding, the specimens were cured in humidity cabinet at $100 \%$ relative humidity at room temperature for 24 hours in order to attain the setting of the specimens. The specimens then were demolded and cured under tap water for various hydration periods: 3, 7, 28 and 90 days. After the predetermined curing time (3, 7, 28 and 90 
days), groups of three specimens were used to determine the residual compressive strength according to ASTM specification (ASTM, 1992C ). Total porosity was determined after each time of hydration as described elsewhere [11]. The hydration of cement pastes were stopped by employing alcohol-acetone method [12]. The samples were dried at $105^{\circ} \mathrm{C}$ for one hour and then collected in polyethylene bags; sealed and stored in desiccators for analysis. The degree of hydration was followed by determination of free lime $[13,14]$. The hydration products were analyzed by FTIR spectrophotometric technique using a Perkin-Elmer System 2000 FTIR spectrometer. The morphology and microstructure of some dry samples were investigated using scanning electron microscope (JEOL JSM-840SEM).

\section{Results and discussion}

Compressive strength:

The compressive strength of PC-MK specimens at different firing temperatures of $\mathrm{KK} 700,800,900$ and $1000{ }^{\circ} \mathrm{C}$ are shown in Figs. 1, 2, 3 and 4, respectively. It is clear that the compressive strength values increased continuously with increasing age of hydration. Comparing the strength values of all specimens of mixes CI, CII, CIII, CIV and CV with blank PC specimen (B), it is clear that MK improves the strength of cement mortars at firing temperatures 800,900 and $1000^{\circ} \mathrm{C}$ of $\mathrm{KK}$ at all ages of hydration. When MK is utilized in cement, the reaction mechanism can be divided to physical and chemical aspects $[15,16]$.The physical effect is that the ultrafine particles fill the voids in cement, which makes the microstructure of cement paste denser. The chemical effect is the reaction of MK with the cement hydrates. The reaction of MK with cement hydrates is fast because $\mathrm{MK}$ has a loose microstructure after thermal activation at a temperature of $800^{\circ} \mathrm{C}$ ( the chemically bound water in kaolin was driven out at higher temperatures, and water molecules enter MK more easily when met with water again). Mix CI ( 95\%PC : 5\% MK) which is richer in PC contents possess higher strength values at all stages of hydration and at all firing temperatures of $\mathrm{KK}\left(700,800,900,1000^{\circ} \mathrm{C}\right)$ when compared with mixes CII, CIII , CIV and CV. Evidently, the larger PC content in the solid PC-MK mixture gives rise to a larger amount of the cement hydration products upon hydration ; in addition ; a larger quantity of free $\mathrm{Ca}(\mathrm{OH})_{2}$ will be released as a result of $\mathrm{PC}$ hydration, which in turns increases the hydraulic reactivity of MK which absorbs $\mathrm{Ca}(\mathrm{OH})_{2}$ to produce secondary CSH gel inside the cement paste $[15,16]$. The secondary formed $\mathrm{CSH}$ gel improves the microstructure of cement paste matrix and produce higher compressive strength values of cement 
pastes. The compressive strength values decreased gradually by increasing the MK contents in PC-MK pastes at all firing temperatures of KK. This is attributed to the decreasing in released $\mathrm{Ca}(\mathrm{OH})_{2}$ due to $\mathrm{PC}$ hydration, less formed $\mathrm{CSH}$ and increase the possibility of replacement of $\mathrm{Al}$ for $\mathrm{Si}$ in the $\mathrm{CSH}$ to form hydrogarnet. The latter phase as well as the consumption of $\mathrm{CSH}$ in this reaction decreases the strength of the cured specimens. In addition, the increase in the MK content in PCMK mixes resulted in an increase in the optimum water of consistency (initial porosity ) of the PC-MK pastes; this leads to higher porosity values for the pastes made with MK contents higher than $5 \%$ which is associated with a consequent decrease in their strength values.



Fig.(1): Compressive strength of hardened specimens ( mixes CI-CV ) made from PC and MK (burnt KK at $700^{\circ} \mathrm{C}$ ) as a function of curing time.

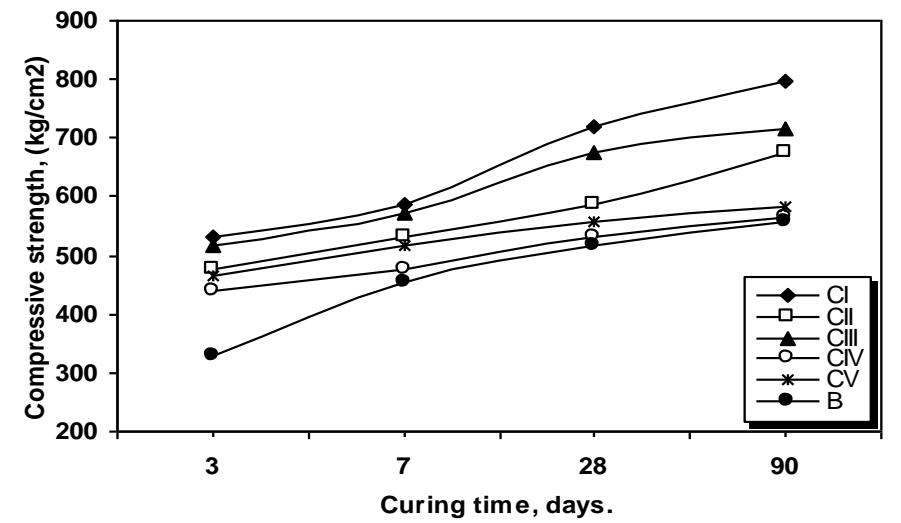

Fig.(2): Compressive strength of hardened specimens ( mixes CI-CV ) made from $\mathrm{PC}$ and $\mathrm{MK}$ (burnt $\mathrm{KK}$ at $800^{\circ} \mathrm{C}$ ) as a function of curing time. 


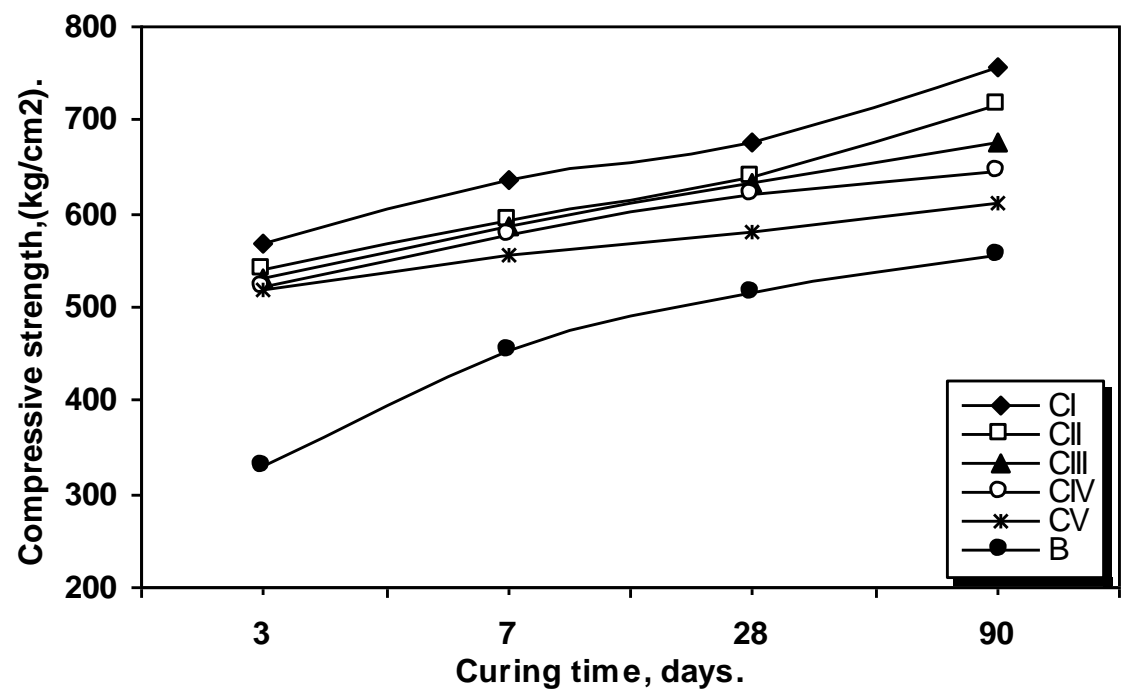

Fig.(3): Compressive strength of hardened specimens ( mixes CI-CV ) made from $\mathrm{PC}$ and $\mathrm{MK}$ (burnt $\mathrm{KK}$ at $900^{\circ} \mathrm{C}$ ) as a function of curing time.

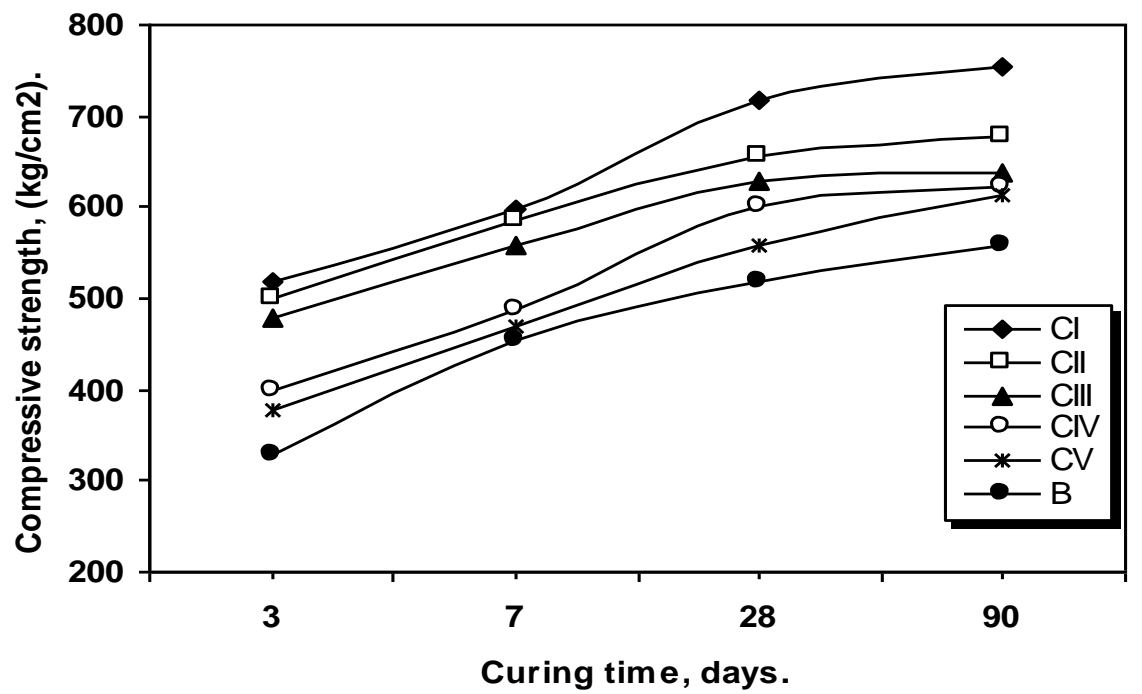

Fig.(4): Compressive strength of hardened specimens (mixes CI-CV) mad from $\mathrm{PC}$ and MK (burnt $\mathrm{KK}$ at $1000^{\circ} \mathrm{C}$ ) as a function of curing time. 


\section{Total Porosity:}

The total porosity values of the hardened PC-MK pastes produced by firing KK at different firing temperatures $\left(700,800,900\right.$ and $\left.1000^{\circ} \mathrm{C}\right)$ as a function of curing time are plotted against curing time as shown in Figs.( 5, 6, 7 and 8 ). The results show that for all pastes, the porosity decreased as the curing age increased. The pastes containing MK had lower porosity values than those of control paste (B: $100 \%$ PC) at all hydration ages. This indicates that the MK used in this study is effective in the refinement of the pore structure of the blended cement system due to the accumulation of hydration products in the open pores of cement pastes. The cement pastes containing $25 \% \mathrm{MK}$ (mix CV) showed higher porosity than all mixes (CI, CII, CIII and CIV); this is mainly due to the higher water of consistency (higher initial porosity) of the PC-MK paste having higher MK contents. These present results are however similar to those obtained by Khatib and Wild [17] and Frias and Cabrera [18], who reported higher porosity values were obtained for high MK content pastes in blended cement.

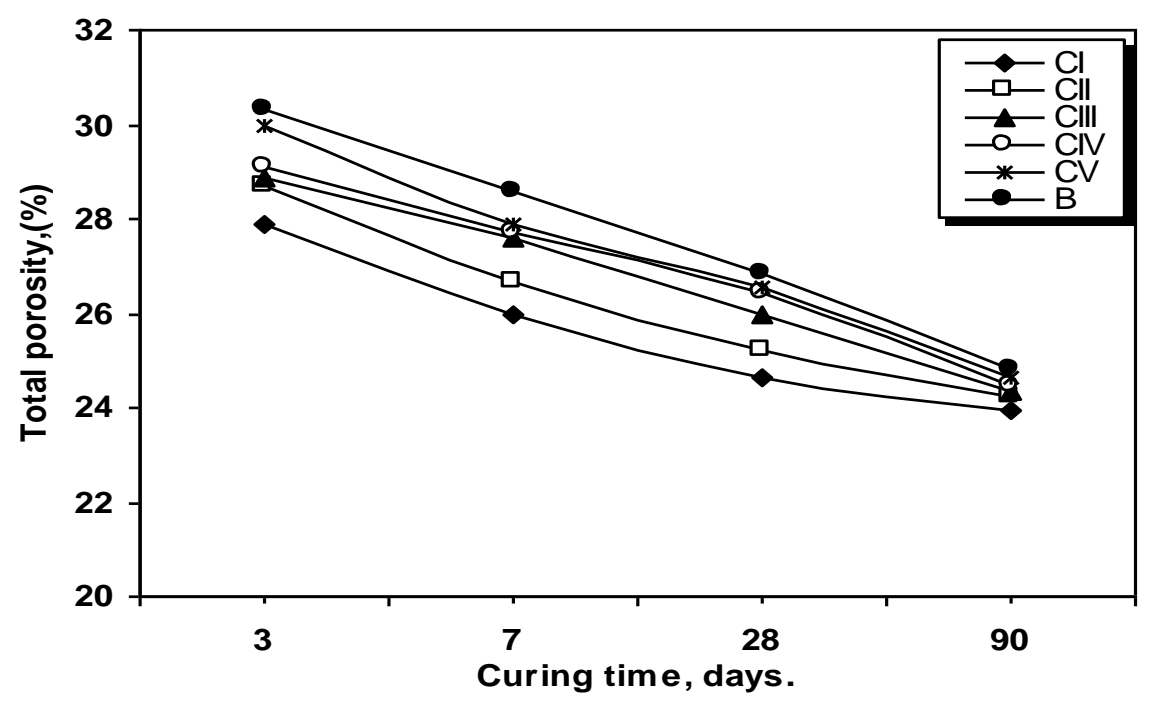

Fig.(5): Total porosity of hardened specimens ( mixes CI-CV ) made from PC and MK ( burnt $\mathrm{KK}$ at $7^{\circ} 0^{\circ} \mathrm{C}$ ) as a function of curing time. 


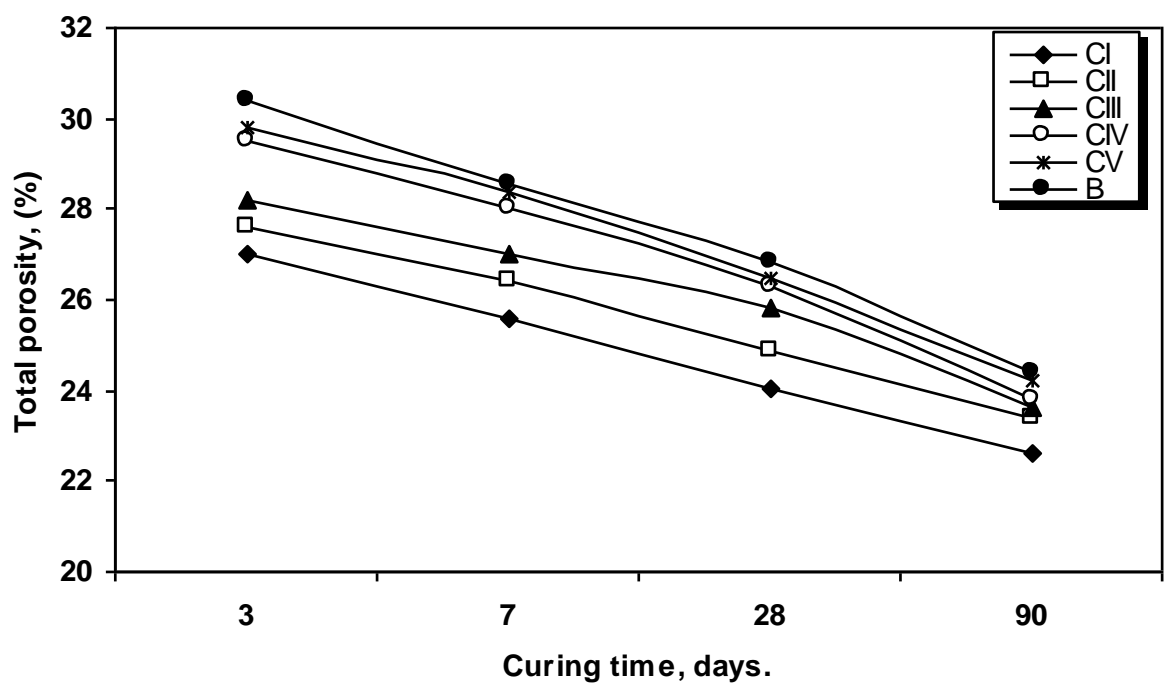

Fig.(6): Total porosity of hardened specimens ( mixes CI-CV ) made from PC and MK (burnt $\mathrm{KK}$ at $800^{\circ} \mathrm{C}$ ) as a function of curing time.

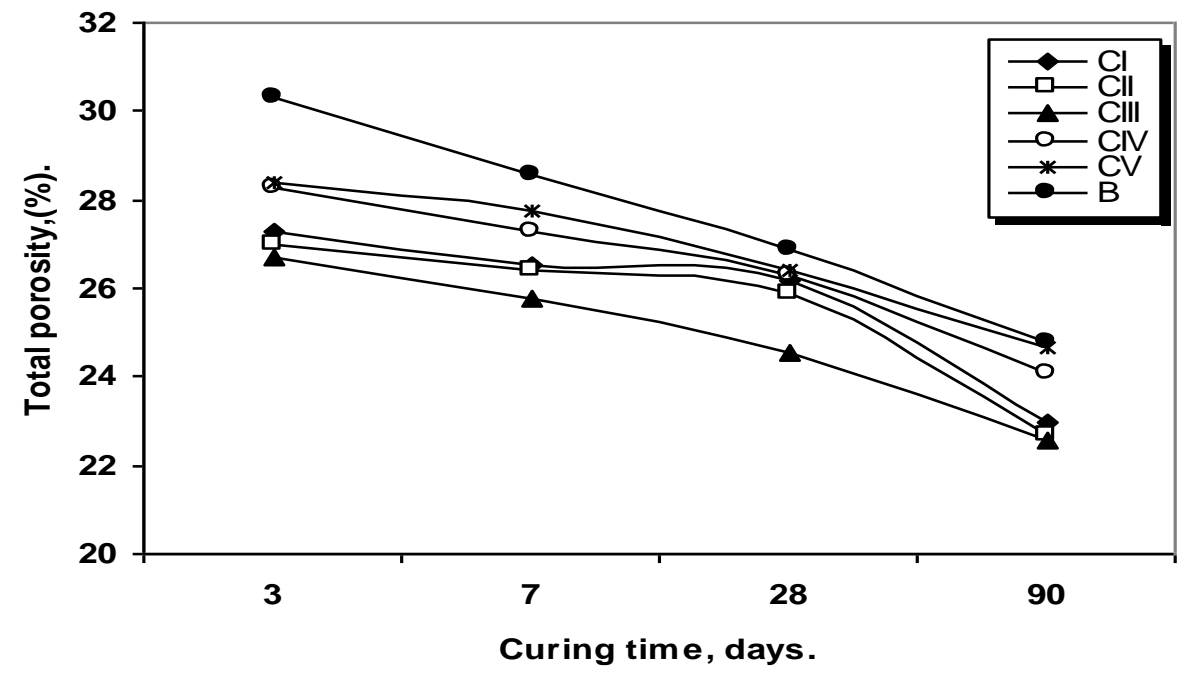

Fig.(7):Total porosity of hardened specimens ( mixes CI-CV ) made from PC and MK (burnt $\mathrm{KK}$ at $900^{\circ} \mathrm{C}$ ) as a function of curing time. 


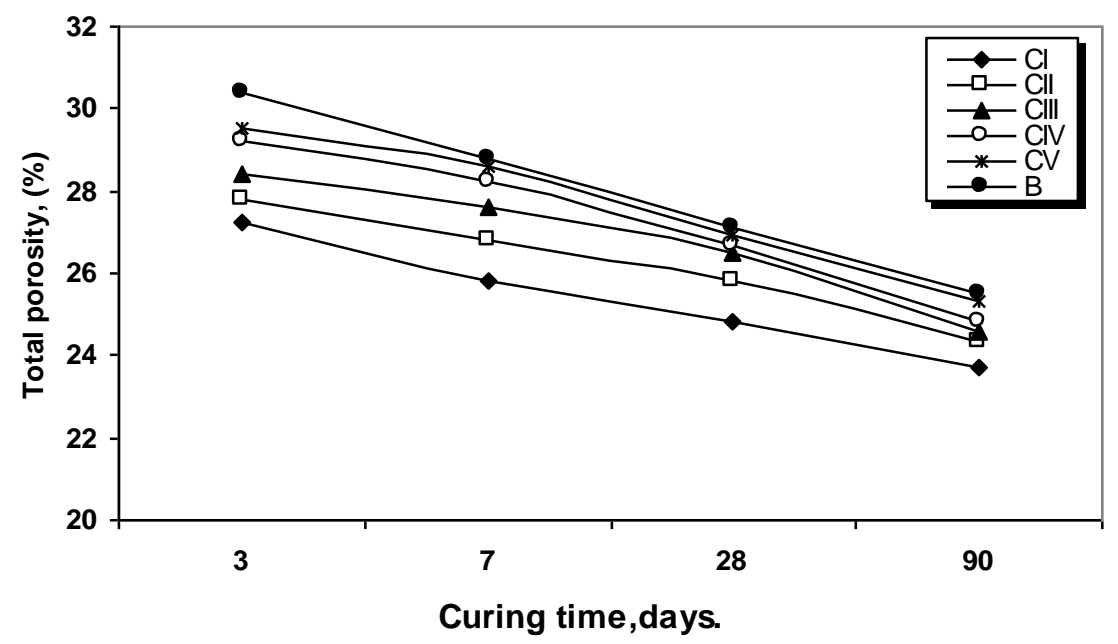

Fig.(8): Total porosity of hardened specimens ( mixes CI-CV ) made from PC and MK (burnt $\mathrm{KK}$ at ${ }^{1000^{\circ}} \mathrm{C}$ ) as a function of curing time.

Free lime contents:

The free lime contents, $\mathrm{CaO} \%$, of the hardened pastes made from the dry PCMK mixes produced by firing KK at different temperatures (700, 800, 900 and $1000^{\circ} \mathrm{C}$ ) as a function of curing time up to 90 days of water curing are graphically plotted as a function of curing time in Figs.(9, 10, 11 and 12). The determination of free lime gives an idea about the behavior of the solid state reaction between the phases of PC and water as well as between the liberated lime and MK constituents. The detection of free lime for PC pastes is mainly due to the hydration of $\mathrm{C}_{3} \mathrm{~S}$ and $\beta$ $\mathrm{C}_{2} \mathrm{~S}$. Generally, the free lime contents decreases with increasing curing time for all PC-MK pastes and for all firing temperatures of KK. This is mainly attributed to the reaction between the liberated $\mathrm{Ca}(\mathrm{OH})_{2}$ and the active $\mathrm{Al}_{2} \mathrm{O}_{3}$ and $\mathrm{SiO}_{2}$ of $\mathrm{MK}$. These minerals are formed as a result of dissociation of shale/clay due to calcinations at different temperatures $\left(700,800,900\right.$ and $\left.1000^{\circ} \mathrm{C}\right)$. It is clear that the free lime contents for pastes containing fired $\mathrm{KK}$ at 900 and $1000^{\circ} \mathrm{C}$ were smaller than pastes containing fired $\mathrm{KK}$ at 700 and $800^{\circ} \mathrm{C}$ which attributed to the activation of $\mathrm{KK}$ by increasing firing temperature. The addition of more MK consumes all the amount of liberated lime in the reaction with $\mathrm{Al}_{2} \mathrm{O}_{3}$ or $\mathrm{SiO}_{2}$ with water to form hydrated phases of calcium silicate or calcium aluminosilicate. Also, increasing the amount of $\mathrm{MK}$ means increasing $\mathrm{SiO}_{2}$ and $\mathrm{Al}_{2} \mathrm{O}_{3}$ contents. These oxides may have 
chance to react with liberated $\mathrm{Ca}(\mathrm{OH})_{2}$ to form hydrogarnet which has weaker hydraulic properties. Accordingly, the low hydraulic properties obtained for mixes CIII, CIV and CV in this investigation may be attributed to the formation of hydrogarnet; while the increase in the initial porosity of pastes made of these mixes (higher water of consistency) leads to lower strength values.

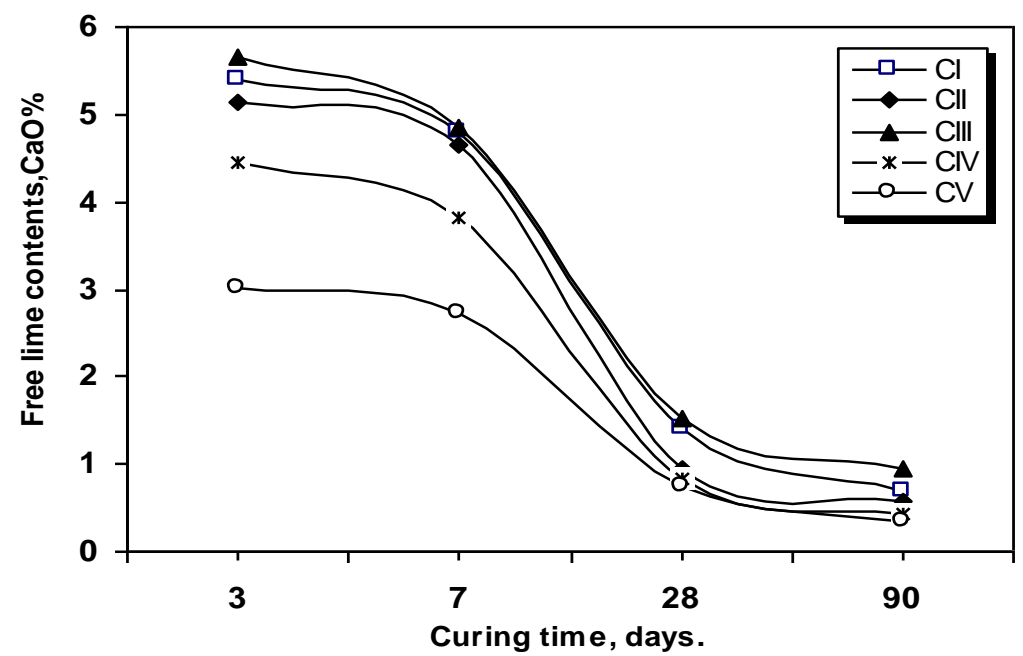

Fig.(9): Free lime contents of hardened specimens ( mixes CI-CV ) made from PC and MK ( burnt $\mathrm{KK}$ at $700^{\circ} \mathrm{C}$ ) as a function of curing time.

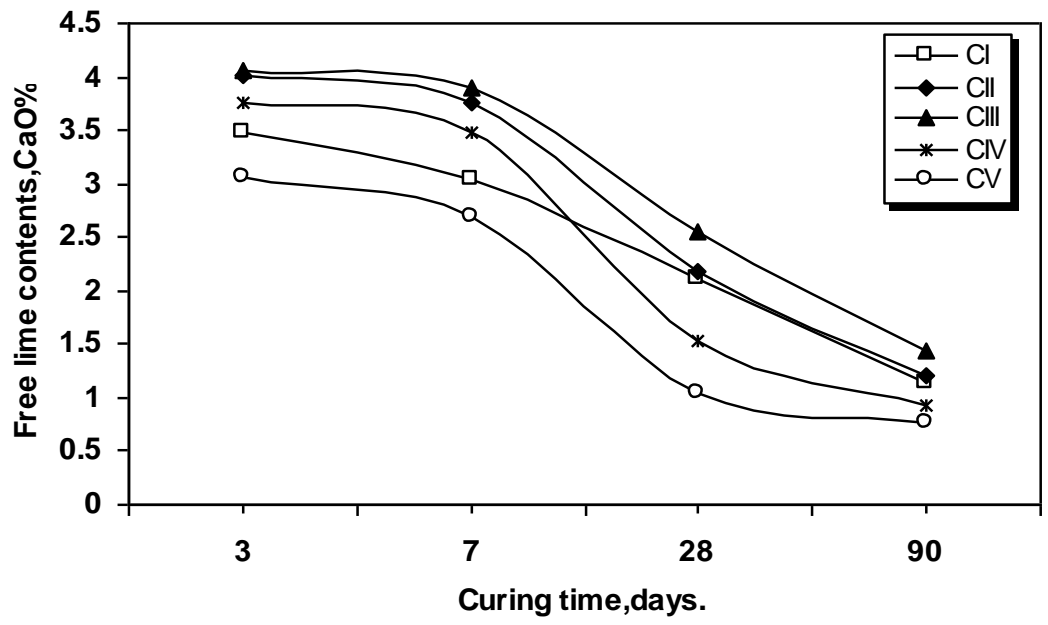

Fig.(10): Free lime contents of hardened specimens ( mixes CI-CV ) made from PC and MK ( burnt $\mathrm{KK}$ at $800^{\circ} \mathrm{C}$ ) as a function of curing time. 


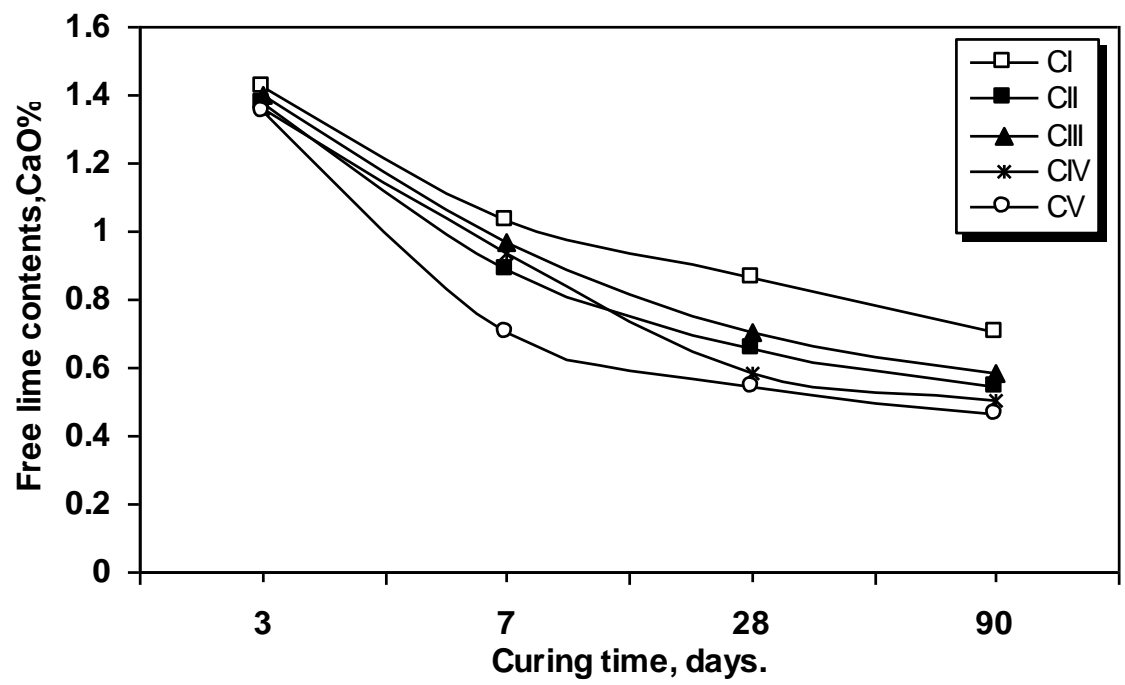

Fig.(11): Free lime contents of hardened specimens ( mixes CI-CV ) made from PC and MK ( burnt $\mathrm{KK}$ at $900^{\circ} \mathrm{C}$ ) as a function of curing time.

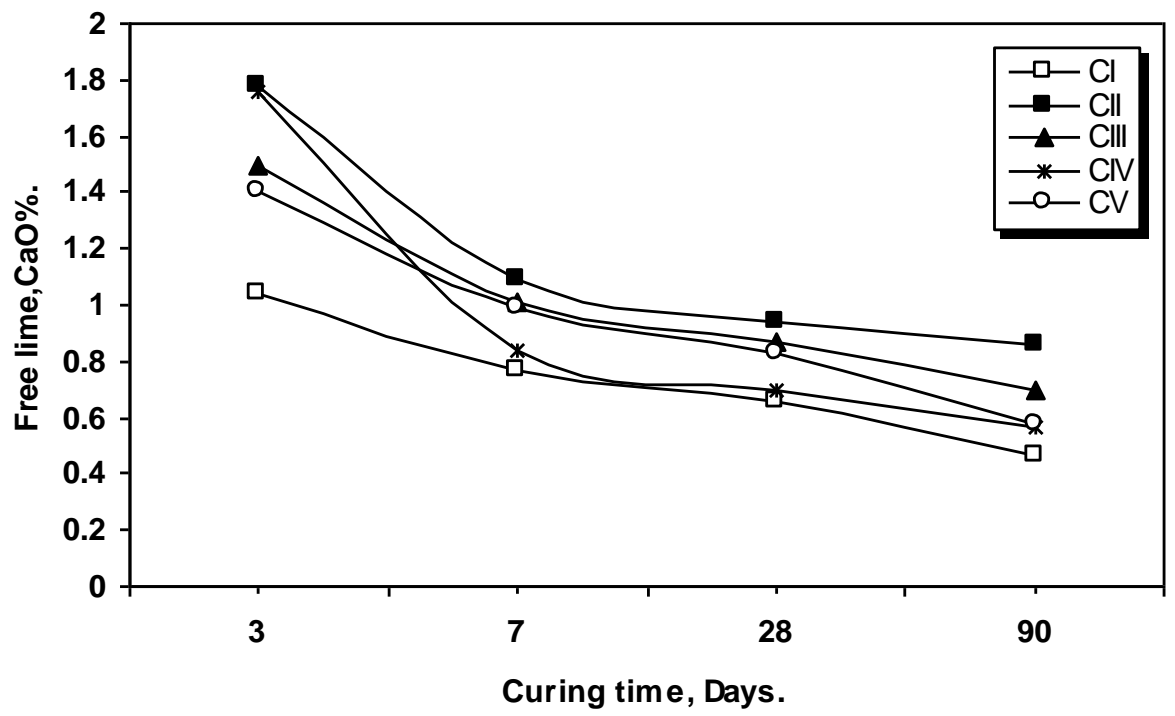

Fig.(12): Free lime contents of hardened specimens ( mixes CI-CV ) made from PC and MK ( burnt $\mathrm{KK}$ at ${ }^{1000^{\circ}} \mathrm{C}$ ) as a function of curing time. 


\section{FTIR spectroscopic study:}

The infrared spectra of mix CI containing fired $\mathrm{KK}$ clay at $800^{\circ} \mathrm{C}$ after $3,7,28$ and 90 days of curing are seen in Fig.(13). It is clear that the intensities of broad band at $3448 \mathrm{~cm}^{-1}$ and weak peak at $1656 \mathrm{~cm}^{-1}$, which are both related to combined water [19], increased with curing time. The bands at 1458 and $876 \mathrm{~cm}^{-1}$ are attributed to presence of calcite, possibly formed due to aeration of the pastes [20]. Also, it is clear that the peak at $1014 \mathrm{~cm}^{-1}$ is attributed to formation or transformation of $\mathrm{CSH}$ [21], increased with curing time. IR spectra corresponding to hydrated PC-MK pastes of mixes CI-CV containing KK clay fired at $800^{\circ} \mathrm{C}$ and $900^{\circ} \mathrm{C}$ after 90 days curing are illustrated in Figs.(14\&15), respectively. It is clear that the intensities of broad bands at 3456 and $3424 \mathrm{~cm}^{-1}\left(800 \& 900^{\circ} \mathrm{C}\right.$, respectively) due to combined water varied with the variation of MK content in the pastes. Mix CI possesses lowest intensity while mix CV has the highest intensity. This is attributed to the highest pozzolana content of mix $\mathrm{CV}$ which need more water molecules for hydration process. There are two bands at 1460 and $1438 \mathrm{~cm}^{-1}$ for $800^{\circ} \mathrm{C}$ and $900^{\circ} \mathrm{C}$, respectively, which are both related to carbonation of samples by absorbing $\mathrm{CO}_{2}$ from the air forming $\mathrm{CaCO}_{3}$ during the hydration process [21]. Generally, Mix CI has the lowest band intensity at different firing temperatures $\left(800^{\circ} \mathrm{C}\right.$ and $\left.900^{\circ} \mathrm{C}\right)$, so it has lowest $\mathrm{CaCO}_{3}$ content which causes an increasing in the rate of hydration process due to lowest carbonation. The bands at 1034 and $1028 \mathrm{~cm}^{-1}\left(800 \& 900^{\circ} \mathrm{C}\right.$, respectively) are related to $\mathrm{CSH}$ (tobermorite) formation [20]. The intensity of these bands increased with increasing MK contents due to the production of more CSH products with different phases. There is a weak band appear at $540 \mathrm{~cm}^{-1}\left(800^{\circ} \mathrm{C}\right.$ only) due to Al-O , hydrogarnet or Ca-O of C-A-H [21].The intensity of this band increased with increasing MK content due to increasing of $\mathrm{Al}$ contents. Finally, it is clear from IR spectroscopic analysis that mix CI has the highest hydraulic properties of PC-MK pastes. 


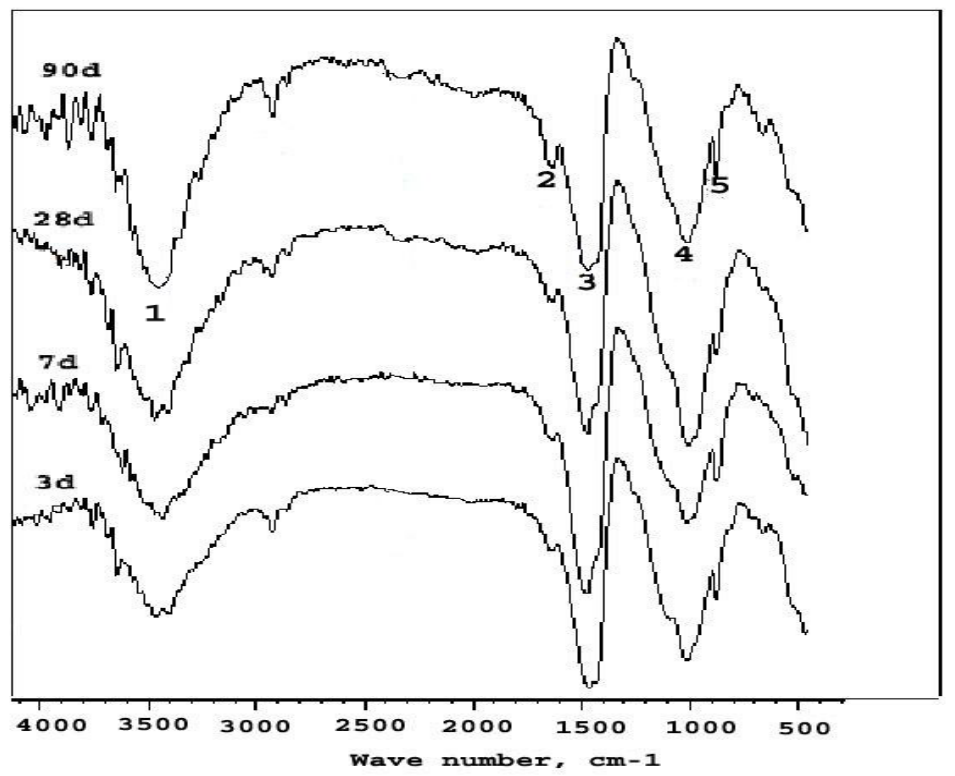

Fig.(13): IR spectra of hydrated mix CI at $800^{\circ} \mathrm{C}$ calcining temperature of $\mathrm{KK}$ clay after $3,7,28$ and 90 days curing.

( $1=3448 \mathrm{~cm}^{-1}, 2=1656 \mathrm{~cm}^{-1}, 3=1458 \mathrm{~cm}^{-1}, 4=1014 \mathrm{~cm}^{-1}, 5=876 \mathrm{~cm}^{-1}$ )



Fig.(14): IR spectra of hydrated mixes (CI-CV) containing calcined KK clay at $800^{\circ} \mathrm{C}$ after 90 days curing.

$$
\left(1=3456 \mathrm{~cm}^{-1}, 2=1460 \mathrm{~cm}^{-1}, 3=1034 \mathrm{~cm}^{-1}, 4=540 \mathrm{~cm}^{-1}\right)
$$






Fig.(15): IR spectra of hydrated mixes (CI-CV) containing calcined KK clay at $900^{\circ} \mathrm{C}$ after 90 days curing.

$$
\left(1=3424 \mathrm{~cm}^{-1}, 2=1438 \mathrm{~cm}^{-1}, 3=1028 \mathrm{~cm}^{-1}\right)
$$

\section{Morphology and microstructure:}

Eight samples were investigated using scanning electron microscopy (SEM) as representatives for the hardened PC-MK pastes in this study. Four of these samples were made from mix CI (95\% PC: 5\% MK) at the firing temperatures of KK clay $700,800,900$ and $1000^{\circ} \mathrm{C}$ after 90 days curing; their SEM micrographs are shown in Figs. 16, 18, 20 and 22, respectively. The other 4 samples were made from mix CV (75\% PC: $25 \% \mathrm{MK}$ ) at the firing temperature of KK clay 700, 800, 900 and $1000{ }^{\circ} \mathrm{C}$ after 90 days curing; their SEM micrographs are shown in Figs.17, 19, 21 and 23, respectively. The SEM micrographs obtained for the specimens of mix CI at firing 
temperature $700^{\circ} \mathrm{C}$ after 90 days curing [Fig.16 (a\&b)], displayed a mixture of various hydration products mainly as nearly amorphous and short fibers of $\mathrm{CSH}$. The micrographs of mix $\mathrm{CV}$ at same firing temperature and curing time [(Fig.17 $(a \& b)]$ indicated formation of fibrous and rod-like crystals of hydration products beside flocculent and porous structure. In this paste the wider pores are available for crystallization of the formed hydrates. So, this paste has a lower strength due to the higher porosity. The microstructure obtained after 90 days curing of mix CI containing burnt $\mathrm{KK}$ at $800^{\circ} \mathrm{C}$, showed a dense structure of nearly amorphous CSH as representing the main hydration products [Fig.18 (a\&b)]; accordingly mix CI possessed high hydraulic properties. The micrographs of mix $\mathrm{CV}$ at same firing temperature of KK and curing time [Fig.19 (a\&b)], show thin platelet crystals flat or crumbled and their edges were hexagonal or irregular. Crystals of this kind possessed low hydraulic properties. The SEM micrographs obtained after 90 days curing of mix CI containing calcined $\mathrm{KK} 900^{\circ} \mathrm{C}$ [( Fig.20 a\&b)], showed dense structure of platelet-like hydrates of $\mathrm{CSH}$ and fully crystalline hydrates having closetextured structure with interlocking arrangements.The micrographs also, show longer rod-like particles of $\mathrm{CSH}$. The micrographs of mix $\mathrm{CV}$ at same firing temperature and curing time displayed close-textured, dense and massive structure composed of interlocking fibers and crumpled foils as well as particles with irregular appearance [Fig.21 (a\&b)]. The microstructure obtained after 90 days curing of mix CI containing burnt $\mathrm{KK}$ at $1000^{\circ} \mathrm{C}$, indicated the formation of amorphous hydrates and a massive structure of ill-crystallized CSH with dense structure [Fig.22 (a\&b)]. The SEM micrographs of mix CV at same firing temperature of KK and same curing time, showed formation of nearly amorphous CSH as well as some cubic crystals of hydrogarnet-like calcium alumino-silicate hydrate [Fig.23 (a\&b)]. From the morphology and microstructure studies in this investigation it is clear that specimens made from mix CI (95\% PC: $5 \% \mathrm{MK}$ ) possess the highest hydraulic properties than specimens made from mix CV (75\% PC: $25 \% \mathrm{MK}$ ) for all firing temperatures of $\mathrm{KK}$ and all curing times. These results are in a good agreement with the obtained physico-chemical measurements of these PC-MK pastes. 


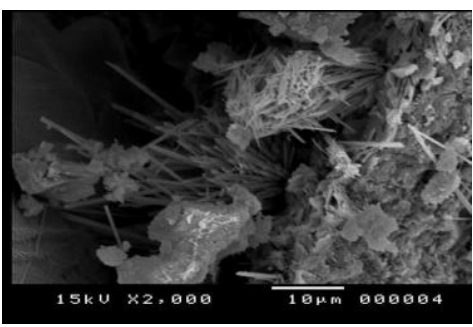

(a)



(b)

Fig.(16): SEM micrographs of mix CI contains calcined $\mathrm{KK}$ at $700^{\circ} \mathrm{C}$ after 90 days curing.

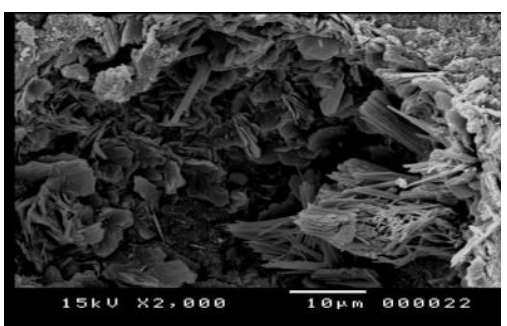

(a)

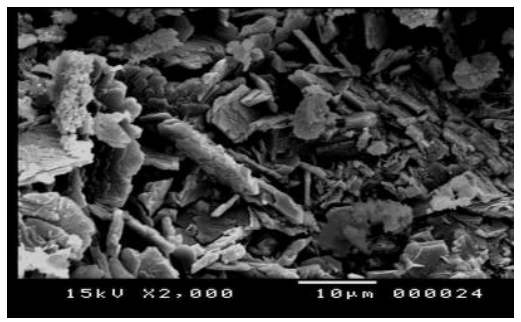

(b)

Fig.(17): SEM micrographs of mix $\mathrm{CV}$ contains fired $\mathrm{KK}$ at $700^{\circ} \mathrm{C}$ after 90 days curing

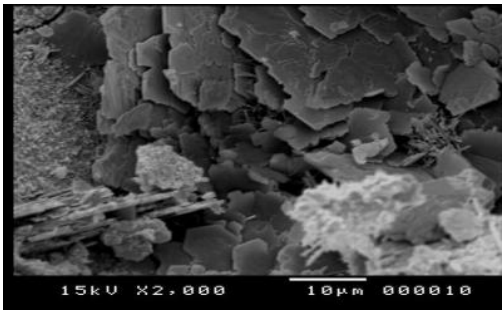

(a)

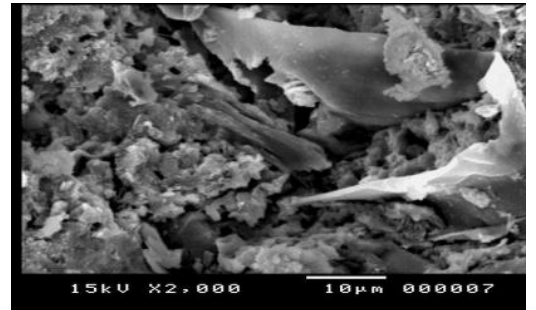

(b)

Fig.(18): SEM micrographs of mix CI contains calcined $\mathrm{KK}$ at $800^{\circ} \mathrm{C}$ after 90 days curing.

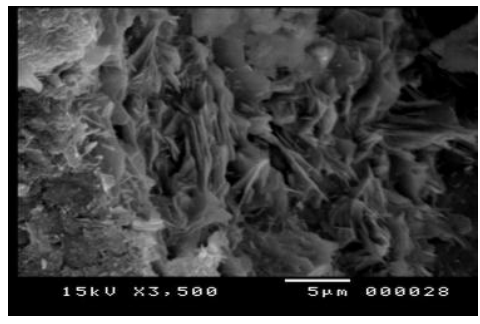

(a)



(b)

Fig.(19): SEM micrographs of mix $\mathrm{CV}$ contains calcined $\mathrm{KK}$ at $800^{\circ} \mathrm{C}$ after 90 days curing 


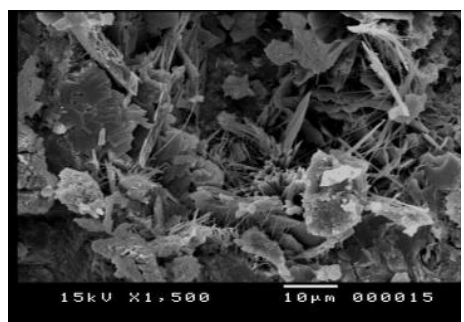

Fig.(20): SEM micrographs of mix CI contains calcined $\mathrm{KK}$ at $900^{\circ} \mathrm{C}$ after 90 days curing.

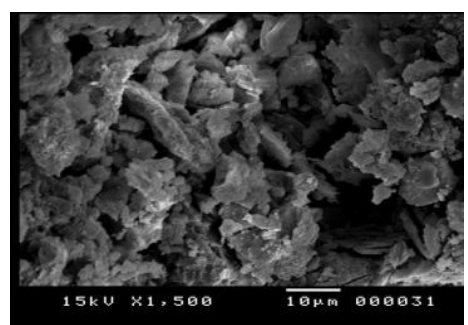

(a)

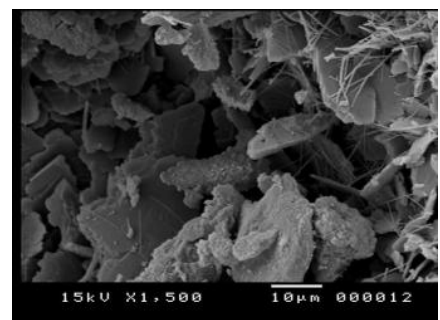

(a) (b)

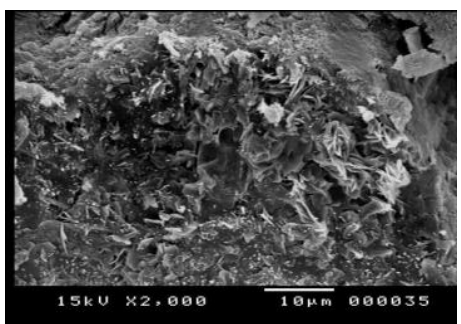

(b)

Fig.(21): SEM micrographs of mix CV contains calcined $\mathrm{KK}$ at $900^{\circ} \mathrm{C}$ after 90 days curing.

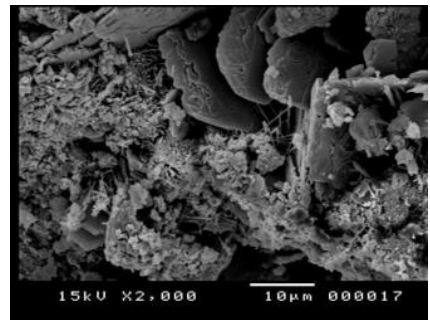

(a)

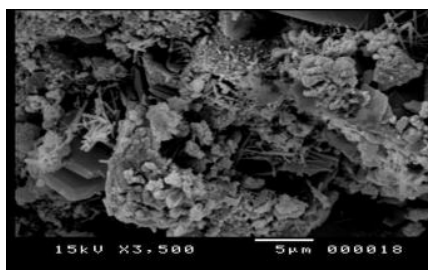

(b)

Fig.(22): SEM micrographs of mix CI contains calcined $\mathrm{KK}$ at $1000^{\circ} \mathrm{C}$ after 90 days curing

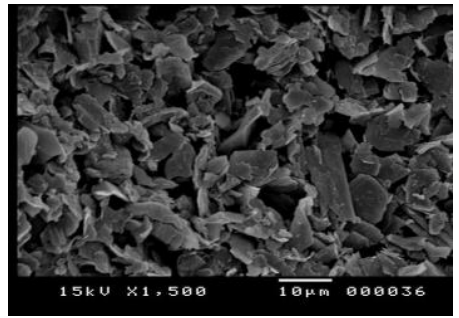

(a)

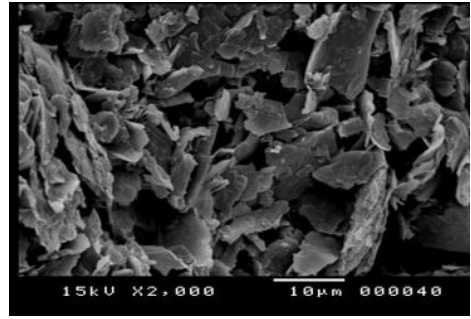

(b)

Fig.(23): SEM micrographs of mix $\mathrm{CV}$ contains calcined $\mathrm{KK}$ at $1000^{\circ} \mathrm{C}$ after 90 days curing 


\section{Conclusions}

From this study we can conclude that:

1- The compressive strength of the various PC-MK pastes increases continuously with increasing age of hydration up to 90 days for all calcining temperatures of KK clay. Mix CI( 95\% PC: 5\% MK) possess the highest compressive strength values at all calcining temperatures and all times of curing, the optimum value of compressive strength was at $800^{\circ} \mathrm{C}$ after 90 days of curing.

2- The porosity values decreased for all types of mixes at all curing times and all firing temperatures of KK clay. Generally, Mix CI possesses lower porosity values at all firing temperatures of clay and all curing times which is in harmony with compressive strength results.

3- The results of free lime contents indicate that the free lime was consumed gradually with increasing age of hydration for all types of the hardened PC-MK pastes.

4- The infrared spectroscopic analysis of some PC-MK pastes indicated the appearance of bands at different wave lengths due to formation of different phases. For all selected samples there are different bands appear due to combined water, carbonation, $\mathrm{CSH}$ and $\mathrm{CAH}$ formation with variation of intensities according to the mix composition, firing temperature and curing time. Generally, mix CI (95\% PC: 5\% MK) has improved hydraulic properties.

5- The morphology and microstructure of studied hardened PC-MK pastes of mix CI showed formation of nearly amorphous and short fibers of $\mathrm{CSH}$, dense structure of nearly amorphous CSH, dense structure of platelet-like hydrates of $\mathrm{CSH}$ and fully crystalline hydrates having close-textured structure with interlocking arrangements and a massive structure of ill-crystallized CSH with dense structure.

6- Finally, this study indicated that partial substitution of ordinary Portland cement with $5 \%$ to $25 \%$ burnt Kalabsha kaolinite clay at $800^{\circ} \mathrm{C}$ will produce pozzolanic cement with higher hydraulic properties than ordinary Portland cement and the optimum substitution value is $5 \%$ burnt Kalabsha kaolinite clay at $800^{\circ} \mathrm{C}$. 


\section{References}

1. D.S. KLIMESCH AND A. RAY, Adv. Cem. Based Mater., 7, 109-118 (1998).

2. H. EL-DIDAMONY, K.A. KHALIL AND M.S. EL-ATTAR, Cem. Concr. Res., 30, 7-11 (2000).

3. H. CHANGLing, B. OSBAECK AND E. MAKOVICKY, Cem. Concr. Res., 25(8), 1691-1702 (1995).

4. M.H. ZHANG AND V.M. MALHOTRA, Cem. Concr. Res., 25(8), 1713-1725 (1995).

5. T. RAMLOCHAN, M.D.A.THOMAS AND R.D. HOOTON, Cem. Concr. Res.,34(8), 1341-1356 (2004).

6. L. COURARD, A. DARIMONT, M. SCHOUTERDEN, F. FERAUCHE, X.Willem and R. Degeimbre, Cem. Concr. Res., 33(9), 1473-1479 (2003).

7. E. BADOGIANNIS, G. KAKALI, G. DIMOPOULOU, E. CHANIOTAKIS AND S. TSIVILIS, Cem. Concr. Composite, 27(2), 197-203 (2005).

8. XI. QIAN AND Z. LI, CEM.Concr.Res, 31, 1607-1611 (2001).

9. C.S. POON, L. AM, S.C. KOU, Y. WONG AND R.WONG, Cem. Concr. Res., 31, 13011306 (2001).

10. G. BATIS, P. PANTAZOPOULOU, S. TSIVILIS AND E. BADOGIANNIS, Cem. Concr. Composite, 27(1), 125-130 (2005).

11. M. ABD EL AZIZ, S. ABD EL ALEEM , M. HEIKAL AND H. EL-DIDAMONY , Silicate Industriels., 68(1/2),73-84 (2004).

12. H. EL-DIDAMONY , S.A. ABO-EL-ENEIN AND M.Y. HAGGAG , Cem. Concr. Res., 8, 351 (1978).

13. M.P. JAVELLANA AND I. JAWED , Cem. Concr. Res., 12, 399-403 (1982).

14. Soroka ," Portland cement past and concrete". New York: Macmillan; 1970.

15. Z. DING, D. ZHANG AND Y. XIE, J. Build. Mater. , 1, 201-205 (1998)

16. Z. DING, D. ZHANG AND R.YU, China. Mater. Sci. Technol., 1, 14-17 (1999).

17. J.M. KHATIB AND S.WILD, Cem. Concr. Res. , 26(10), 1545-553 (1996).

18. M. FRIAS AND J. CABRERA, Cem. Concr. Res. 32(1), 133-138 (2002).

19. N.J. SAIKA, P. SENGUPA, P.K. GOGOI AND P.C. BORTHAKUR, Cem. Concr. Res.,32, 1717-1724 (2002).

20. N.J. SAIKA, P. SENGUPTA, P.K. GOGOI AND P.C. BORTHAKUR, Cem. Concr. Res., 32, 207-302 (2001).

21. F. PUERTAS, H. SANTOS, M. PALACIOS AND S. MARTINZ-RAMIREZ, Advances in Cement Research, 17(2), 77-89 (2005). 
تأثير حرارة حرق طفلة الكاولين على خصائص العجائن المحتوية على الأسمنت البورتلاندى والميتاكاولين

محمود أحمد طاهر، عبد العزيز السيد يوسف ، عثمان عبد المعطى فرغلى ، محمد رضا شتات



ملخص البحث

تعتبر طفلة الكاولين المحروقة ( الميتاكاولين) من أهم المواد البوزولانية ذات النثاطية العالية بسبب

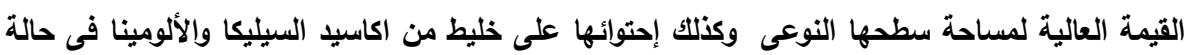

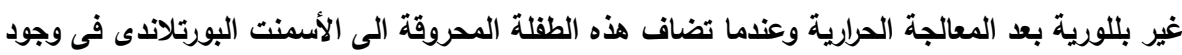



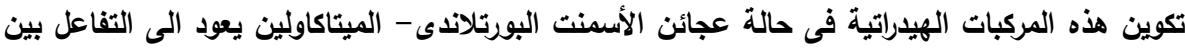

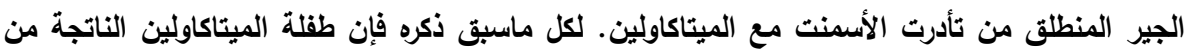

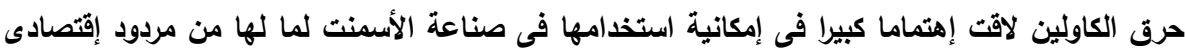
وبيئى.

فى هذا البحث تمت دراسة مدى تأثير استخام طفلة الميتاكاولين الناتجة من حرق طفلة الكاولين (

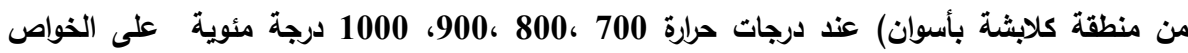



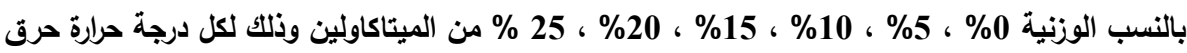

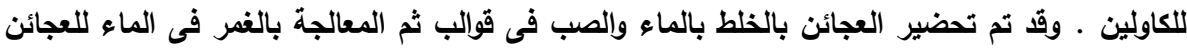

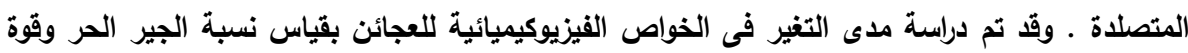

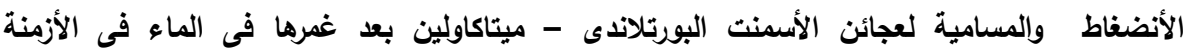


للأثعة تحت الحمراء ( IR spectroscopy ) . . و تمت دراسة التغير في التركيب الاقيق لبعض العينات

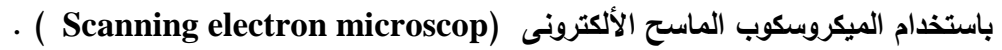

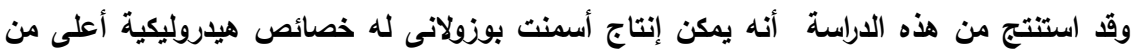

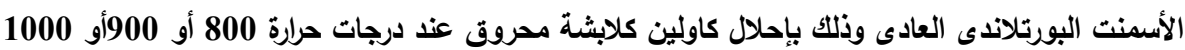

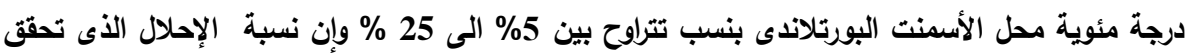
أعلى خصائص هيدروليكية هى 5\% من كاولين كلابثة المحروق عند درجة حرارة 800 درجة مئوية . 